\title{
Trends in Female Employment at the Federal Government Level: A Critical Appraisal of 1983-1989
}

\author{
HINA NAZLI and SAMINA NAZLI
}

\section{INTRODUCTION}

This paper focuses on two aspects. First, it looks at the trends in female employment at the federal level over a period of six years, from 1983 to 1989, based on data from the Federal Government's Civil Servants Census Reports, using three years, 1983, 1986, 1989. The second aspect of the paper is to highlight the fact that not all the information that is collected is published gender-wise. This is very important from the point of view of working women as it can also have strong policy implications with regard to the advancement of women for which the Government has set up a separate ministry. The ignorance of the Ministry of Women's Development about this aspect, that is, of available unpublished information, is surprising.

The paper is structured as follows. After a brief discussion of data and methodology, the results are presented in Section 2. Section 3 discusses the data which are collected but not published at the disaggregate level which has adverse implications for women employees at the policy level. The conclusions and policy recommendations are presented in the final and fourth section of this paper.

The data used in this paper are taken from the Government of Pakistan (1983, 1986, 1989). The statistics reported in these reports are classified by service groups into Secretariat, Attached Departments, Subordinate Offices, Other Offices, and in the Autonomous/Semi-Autonomous bodies by Basic Pay Scale (BPS) and gender. The Censuses show that for these years no female employee of the regular civil service is reported in BPS-22 for all the categories, and also none is reported in BPS 21 in 1989. Therefore, for this analysis, we group the female employees as between BPS 16-20 instead of BPS 16-22.

According to the Census reports, Education, Health, Population Welfare, Special Education and Social Welfare, and Women's Development can be said to be female-

Hina Nazli is Research Economist and Samina Nazli is Staff Economist at the Pakistan Institute of Development Economics, Islamabad. 
intensive departments because of their comparatively higher percentage share in total employment. During 1989, there were 39 percent females in Education, 24 percent in Health, 21 percent in Population Welfare, 20 percent in Special Education and Social Welfare, and 15 percent in Women's Development. The report of the Pakistan Public Administration Research Centre declares the Ministries of Communication, Railways, and Finance as the most labour-intensive ministries according to their employment strength. The relative position and standing of women in the female-intensive departments and in the most labour-intensive departments is also presented in this paper.

In addition, compound growth rates will be computed to show the trends of female employment at the federal level over this six-year period.

\section{RESULTS}

The gender-wise data on the distribution of Federal Government Civil Servants in various offices by BPS are reported in Table 1 . This table shows a significant (almost twofold) increase in the number of female employees over the period of study. However, as a proportion of male employees, this increase is insignificant. The majority of females is concentrated in BPS-7 and this number increase considerably over this period. The number of females working in BPS-16 and above is found to be extremely low. This classification of females by various departments shows that, between 1983 and 1989, the proportion of female employees in almost all the departments doubled; except for the other offices. Table 2 presents the compound growth rates of female employment in each grade during this period. This table indicates that female employment was growing at 17 percent during 1983-1989. The highest growth rate is found in attached departments, and is negative in other offices. Concentrating on Column 1 and Column 2, one can see a decline in the female employment in BPS-13, BPS-8, BPS-6, and BPS-5, while it is increasing in BPS-9, BPS-12, BPS-15 and BPS-10. ${ }^{1}$ At the lowest levels, the maximum growth has occurred in the BPS-4 and BPS-2 category, where mostly packers and laboratory attendants work. This implies the relative concentration of working women in the lower grades.

In Table 3, three groups of BPS for female employees indicate that the majority of women working in BPS-15 and below are concentrated mainly in the attached departments and in the subordinate offices. The higher growth rate of employment in the subordinate offices is due to the higher female employment rate in the Departments of Education, Health, Population Welfare, and Women's Development. During the period 1983-1989, the number of female workers in BPS-16-20 increased from 447 to 1421. In this group, the majority of females belonged to BPS-17 (see Table 1).

${ }^{1}$ Usually field assistants, clerks, teachers, typists, stenotypists, stenographers, and assistants fall in these grades. A fall in the former and rise in the latter categories indicates promotion to the next scale. 


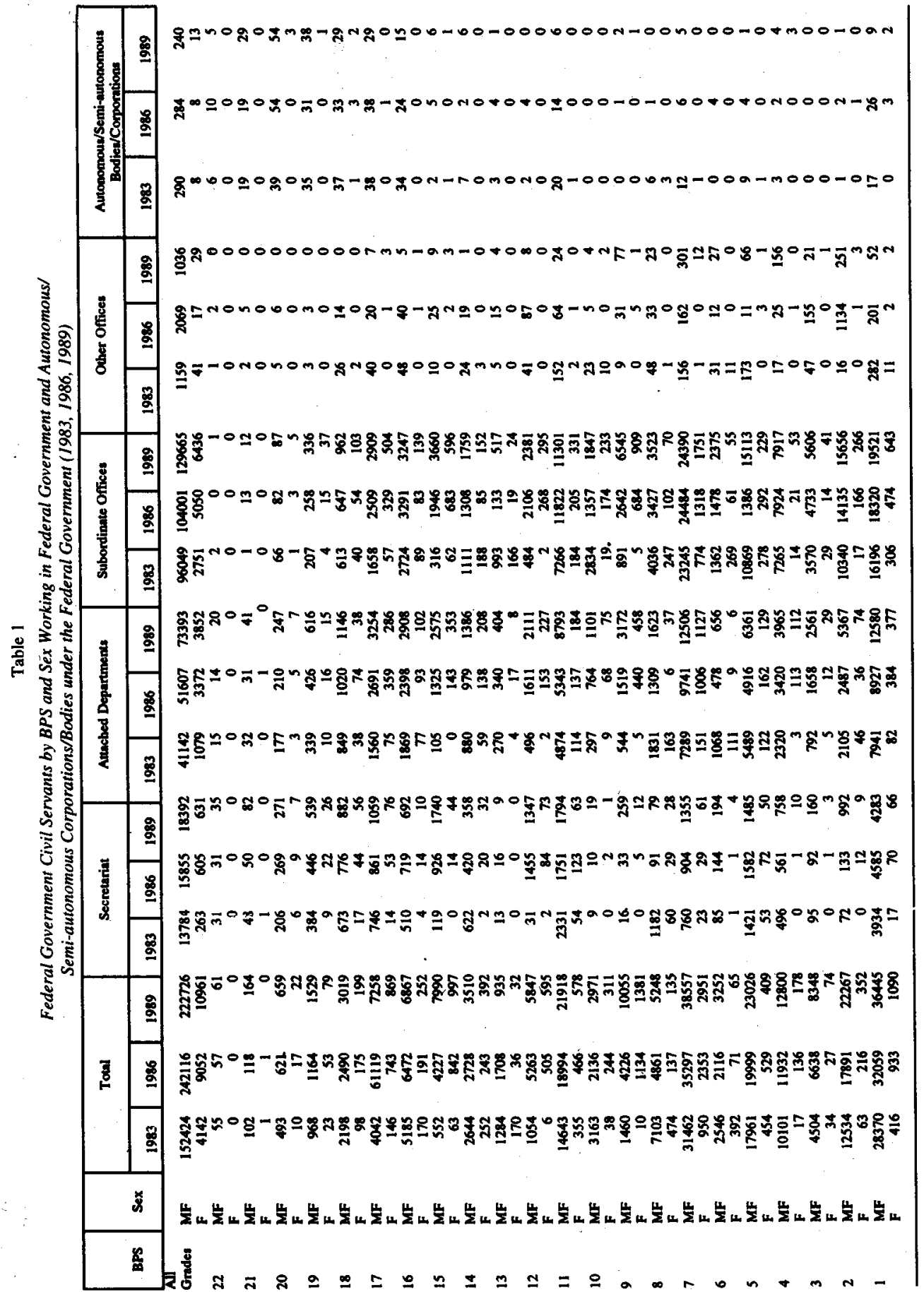


Table 2

Compound Growth Rates of Female Employment at Federal Government and Autonomous/Semi-autonomous Corporations/Bodies under the Federal Government (1983 through 1989)

\begin{tabular}{crrrrrr}
\hline BPS & Total & Secretariat & $\begin{array}{c}\text { Attached } \\
\text { Departments }\end{array}$ & $\begin{array}{c}\text { Subordinate } \\
\text { Offices }\end{array}$ & $\begin{array}{c}\text { Other } \\
\text { Offices }\end{array}$ & $\begin{array}{c}\text { Auto/Semi } \\
\text { Bodies }\end{array}$ \\
\hline All Grades & 17.61 & 15.70 & 23.63 & 15.22 & -5.61 & 8.43 \\
22 & 0.00 & 0.00 & 0.00 & 0.00 & 0.00 & 0.00 \\
21 & 0.00 & 0.00 & 0.00 & 0.00 & 0.00 & 0.00 \\
20 & 14.04 & 2.60 & 15.17 & 30.77 & 0.00 & 0.00 \\
19 & 22.83 & 19.34 & 6.99 & 44.89 & 0.00 & 0.00 \\
18 & 12.53 & 21.98 & 0.00 & 17.07 & 0.00 & 12.25 \\
17 & 34.62 & 32.57 & 24.99 & 43.80 & 0.00 & 0.00 \\
16 & 6.78 & 16.50 & 4.80 & 7.71 & 0.00 & 0.00 \\
15 & 58.45 & 0.00 & 0.00 & 45.82 & 0.00 & 0.00 \\
14 & 7.64 & 58.74 & 23.37 & -3.48 & 0.00 & 0.00 \\
13 & -24.30 & 0.00 & 12.25 & -27.55 & 0.00 & 0.00 \\
12 & 115.14 & 82.13 & 120.04 & 129.86 & 0.00 & 0.00 \\
11 & 8.46 & 2.60 & 8.31 & 10.28 & 0.00 & 0.00 \\
10 & 41.96 & 0.00 & 42.39 & 51.86 & -23.53 & 0.00 \\
9 & 127.35 & 0.00 & 112.32 & 138.01 & 0.00 & 0.00 \\
8 & -18.89 & -11.93 & -12.90 & -18.95 & 0.00 & 0.00 \\
7 & 20.79 & 17.65 & 39.79 & 14.58 & 51.31 & 0.00 \\
6 & -25.88 & 25.99 & -38.51 & -23.25 & 0.00 & 0.00 \\
5 & -1.72 & -0.97 & 0.93 & -3.18 & 0.00 & 0.00 \\
4 & 47.91 & 0.00 & 82.82 & 24.84 & 0.00 & 0.00 \\
3 & 13.84 & 0.00 & 34.04 & 5.94 & 0.00 & 0.00 \\
2 & 33.21 & 0.00 & 8.25 & 58.15 & 0.00 & 0.00 \\
1 & 17.41 & 25.37 & 28.95 & 13.17 & -24.73 & 0.00 \\
\hline
\end{tabular}

According to Table 4, the growth rate is 22 percent and 17 percent in the groups $16-20$ and $1-15$, respectively.

Table 5 displays the number of females in the female-intensive departments and Table 6 present the compound growth rates through 1983-1989 by BPS. The data on Special Education and Social Welfare for 1983 is not available; therefore, we have calculated the growth rate for this category for the period 1986-1989 instead of 19831989. Consequently, the growth rates reported in this column are higher. Looking at the other columns, the growth rates for BPS-16 and above are observed to be higher in each department.

In the Education Department, there was no female in BPS-20, BPS-12, and BPS9 in 1983, but in 1989 this number increased to 4 in BPS-20, 380 in BPS-12, and 1111 in BPS-9. The growth rates indicate an increase in the number of females working in BPS-16 and above; while in BPS-15 and below, female employment in various grades is decreasing. These trends may be caused by the upgradation of employees to higher 
Table 3

Total Number of Females in Federal Government and Autonomous/ Semi-autonomous Corporations/Bodies under the Federal Government in Three Groups of BPS during 1983, 1986, 1989

\begin{tabular}{|c|c|c|c|c|c|c|c|}
\hline Year/BPS & Sex & Total & Secretariat & $\begin{array}{l}\text { Attached } \\
\text { Departments }\end{array}$ & $\begin{array}{c}\text { Subordinate } \\
\text { Offices }\end{array}$ & $\begin{array}{l}\text { Other } \\
\text { Offices }\end{array}$ & $\begin{array}{c}\text { Auto/Semi- } \\
\text { auto Corpo/ } \\
\text { Bodies }\end{array}$ \\
\hline \multicolumn{8}{|l|}{1983} \\
\hline \multirow[t]{2}{*}{$1-20$} & MF & 37843 & 5739 & 12307 & 19166 & 389 & 242 \\
\hline & $\mathrm{F}$ & 4141 & 262 & 1079 & 2751 & 41 & 8 \\
\hline \multirow[t]{2}{*}{$1-15$} & MF & 24800 & 3141 & 7466 & 13895 & 264 & 34 \\
\hline & $\mathrm{F}$ & 3694 & 212 & 876 & 2560 & 39 & 7 \\
\hline \multirow[t]{2}{*}{$16-20$} & MF & 12886 & 2519 & 4794 & 5268 & 122 & 183 \\
\hline & $\mathrm{F}$ & 447 & 50 & 203 & 191 & 2 & 1 \\
\hline \multicolumn{8}{|l|}{1986} \\
\hline \multirow[t]{2}{*}{$1-20$} & MF & 111323 & 7763 & 18671 & 28114 & 336 & 239 \\
\hline & $\mathrm{F}$ & 9051 & 3371 & 631 & 5050 & 17 & 8 \\
\hline \multirow[t]{2}{*}{$1-15$} & MF & 39282 & 4611 & 11881 & 21314 & 246 & 30 \\
\hline & $\mathrm{F}$ & 7872 & 463 & 2824 & 4566 & 15 & 4 \\
\hline \multirow[t]{2}{*}{$16-20$} & MF & 71866 & 3071 & 6745 & 6787 & 83 & 180 \\
\hline & $\mathrm{F}$ & 1179 & 142 & 547 & 484 & 2 & 4 \\
\hline \multicolumn{8}{|l|}{1989} \\
\hline \multirow[t]{2}{*}{$1-20$} & MF & 72783 & 9086 & 27774 & 35564 & 139 & 220 \\
\hline & F & 10961 & 631 & 6436 & 2751 & 29 & 13 \\
\hline \multirow[t]{2}{*}{$1-15$} & MF & 53226 & 5526 & 19542 & 28010 & 127 & 21 \\
\hline & F & 9540 & 456 & 3404 & 5648 & 25 & 7 \\
\hline \multirow[t]{2}{*}{$16-20$} & MF & 19332 & 3443 & 8171 & 5268 & 12 & 165 \\
\hline & F & 1421 & 175 & 448 & 788 & 4 & 6 \\
\hline
\end{tabular}

Table 4

Compound Growth Rates of Female Employment in the Federal Government and Autonomous/Semi-autonomous Corporations/Bodies in Three Groups of BPS (1983 through 1989)

\begin{tabular}{ccccccc}
\hline BPS & Total & Secretariat & $\begin{array}{c}\text { Attached } \\
\text { Departments }\end{array}$ & $\begin{array}{c}\text { Subordinate } \\
\text { Offices }\end{array}$ & $\begin{array}{c}\text { Other } \\
\text { Offices }\end{array}$ & $\begin{array}{c}\text { Auto/Semi } \\
\text { Bodies }\end{array}$ \\
\hline $1-20$ & 17.61 & 15.78 & 23.63 & 15.21 & -5.61 & 8.43 \\
$1-15$ & 17.13 & 13.61 & 25.38 & 14.10 & -7.14 & 2.25 \\
$16-20$ & 21.26 & 23.22 & 14.10 & 26.64 & 12.25 & 34.80 \\
\hline
\end{tabular}




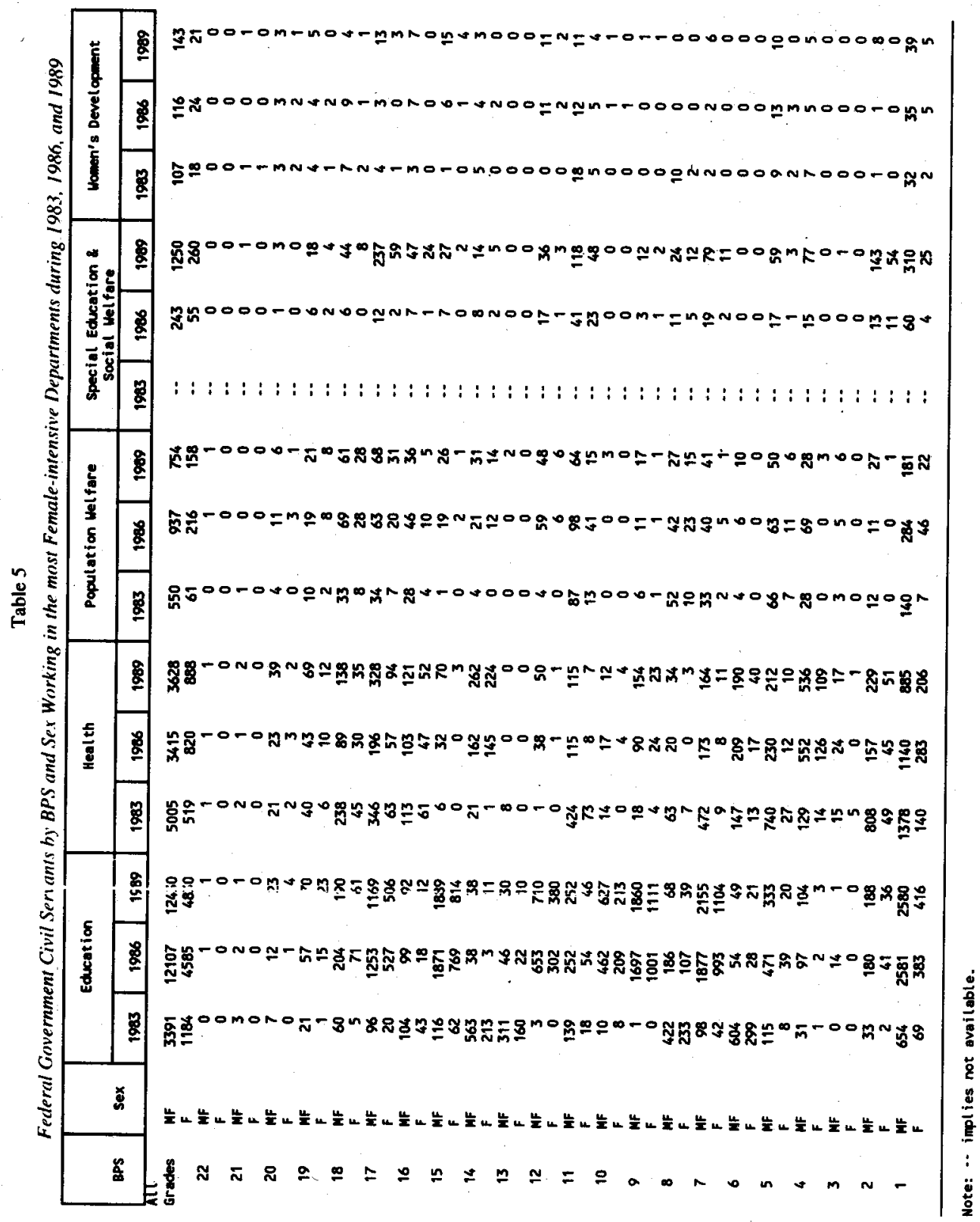


Table 6

Compound Growth Rates of Female Employment in the Most Female-Intensive Departments (1983 through 1989)

\begin{tabular}{|c|c|c|c|c|c|}
\hline BPS & Education & Health & $\begin{array}{c}\text { Population } \\
\text { Welfare }\end{array}$ & $\begin{array}{c}\text { Social } \\
\text { Welfare }\end{array}$ & $\begin{array}{c}\text { Women } \\
\text { Development }\end{array}$ \\
\hline All Grades & 26.41 & 9.36 & 17.19 & 67.83 & 2.60 \\
\hline 22 & NC & NC & NC & $\mathrm{NC}$ & $\mathrm{NC}$ \\
\hline 21 & NC & NC & NC & NC & $\mathrm{NC}$ \\
\hline 20 & NC & 0.00 & NC & NC & -10.9 \\
\hline 19 & 68.64 & 12.25 & 25.99 & 25.99 & NC \\
\hline 18 & 51.73 & -4.10 & 23.22 & NC & -10.91 \\
\hline 17 & 71.34 & 6.90 & 28.15 & 2.08 & 20.09 \\
\hline 16 & -19.16 & -2.63 & 3.79 & 188.45 & $\mathrm{NC}$ \\
\hline 15 & 53.59 & NC & NC & NC & $\mathrm{NC}$ \\
\hline 14 & -38.98 & 146.44 & NC & 35.72 & NC \\
\hline 13 & -37.00 & NC & NC & $\mathrm{NC}$ & $\mathrm{NC}$ \\
\hline 12 & NC & $\mathrm{NC}$ & NC & 44.22 & $\mathrm{NC}$ \\
\hline 11 & 16.93 & -32.35 & 2.41 & 27.79 & -3.65 \\
\hline 10 & 72.80 & NC & NC & NC & $\mathrm{NC}$ \\
\hline 9 & NC & 33.85 & 0.00 & 25.99 & $\mathrm{NC}$ \\
\hline 8 & -25.76 & -13.17 & 6.99 & 33.89 & $\mathrm{NC}$ \\
\hline 7 & 72.43 & 3.40 & -10.91 & 76.52 & NC \\
\hline 6 & -35.77 & 20.60 & $\mathrm{NC}$ & $\mathrm{NC}$ & $\mathrm{NC}$ \\
\hline 5 & 16.50 & -15.26 & -2.54 & 44.22 & $\mathrm{NC}$ \\
\hline 4 & 20.09 & 40.78 & NC & $\mathrm{NC}$ & $\mathrm{NC}$ \\
\hline 3 & NC & -23.53 & NC & $\mathrm{NC}$ & $\mathrm{NC}$ \\
\hline 2 & 61.89 & 0.67 & $\mathrm{NC}$ & 69.95 & $\mathrm{NC}$ \\
\hline 1 & 34.91 & 6.65 & 21.03 & 84.20 & 16.50 \\
\hline
\end{tabular}

Note: NC implies not computable.

grades. The growth rates for BPS-17 in the departments of Population Welfare, Special Education and Social Welfare, and Women's Development are the highest.

The number of employed persons (total and female) by BPS and their growth rates over the period 1983-1989 in the most labour-intensive departments are reported in Tables 7 and 8 respectively. Table 7 shows that there were very few females in these departments in 1983, especially in BPS-15 and below. This number has considerably increased in 1989. For example, in BPS-15 there was no female in any of these departments, while in 1989 there were 16 women in Communication, 36 in Finance, and 45 in Railways. 
Table 7

Federal Government Civil Servants by BPS and Sex Working in the Most Labour-intensive Departments during 1983, 1986, and 1989

\begin{tabular}{|c|c|c|c|c|c|c|c|c|c|c|}
\hline \multirow[b]{2}{*}{ BPS } & \multirow[b]{2}{*}{ Sex } & \multicolumn{3}{|c|}{ Communication } & \multicolumn{3}{|c|}{ Finance } & \multicolumn{3}{|c|}{ Railways } \\
\hline & & 1983 & 1986 & 1989 & 1983 & 1986 & 1989 & 1983 & 1986 & 1989 \\
\hline \multirow[t]{2}{*}{22} & MF & 1 & 1 & 1 & 7 & 7 & 5 & 1 & 1 & 1 \\
\hline & $\mathrm{F}$ & 0 & 0 & 0 & 0 & 0 & 0 & 0 & 0 & 0 \\
\hline \multirow[t]{2}{*}{21} & MF & 2 & 2 & 2 & 14 & 20 & 25 & 5 & 6 & 7 \\
\hline & $\mathrm{F}$ & 0 & 0 & 0 & 0 & 1 & 0 & 0 & 0 & 0 \\
\hline \multirow[t]{2}{*}{20} & MF & 30 & 38 & 46 & 87 & 101 & 110 & 29 & 26 & 45 \\
\hline & $\mathrm{F}$ & 0 & 0 & 1 & 1 & 4 & 2 & 0 & 0 & 2 \\
\hline \multirow[t]{2}{*}{19} & MF & 67 & 138 & 141 & 170 & 177 & 244 & 78 & 79 & 89 \\
\hline & $\mathrm{F}$ & 1 & 3 & 1 & 2 & 3 & 5 & 0 & 2 & 5 \\
\hline \multirow[t]{2}{*}{18} & MF & 167 & 259 & 378 & 285 & 331 & 537 & 235 & 187 & 202 \\
\hline & $\mathrm{F}$ & 2 & 4 & 2 & 10 & 11 & 16 & 7 & 4 & 3 \\
\hline \multirow[t]{2}{*}{17} & MF & 413 & 684 & 763 & 917 & 1085 & 996 & 316 & 638 & 512 \\
\hline & $\mathrm{F}$ & 3 & 5 & 13 & 15 & 43 & 38 & 4 & 16 & 38 \\
\hline \multirow[t]{2}{*}{16} & MF & 1009 & 1353 & 1494 & 1332 & 1683 & 1757 & 442 & 79 & 839 \\
\hline & $\mathrm{F}$ & 3 & 6 & 12 & 28 & 63 & 70 & 4 & 7 & 12 \\
\hline \multirow[t]{2}{*}{15} & MF & 33 & 161 & 730 & 156 & 413 & 1732 & 86 & 433 & 727 \\
\hline & $\mathrm{F}$ & 0 & 14 & 16 & 0 & 3 & 36 & 0 & 39 & 45 \\
\hline \multirow[t]{2}{*}{14} & MF & 28 & 20 & 82 & 374 & 824 & 891 & 406 & 412 & 768 \\
\hline & $\mathrm{F}$ & 0 & 1 & 3 & 14 & 24 & 27 & 18 & 13 & 53 \\
\hline \multirow[t]{2}{*}{13} & MF & 24 & 160 & 133 & 553 & 1084 & 288 & 88 & 100 & 176 \\
\hline & $\mathrm{F}$ & 0 & 0 & 2 & 6 & 4 & 10 & 0 & 1 & 3 \\
\hline \multirow[t]{2}{*}{12} & MF & 134 & 479 & 543 & 116 & 823 & 869 & 494 & 985 & 1234 \\
\hline & $\mathrm{F}$ & 1 & 14 & 19 & 0 & 40 & 40 & 2 & 17 & 30 \\
\hline \multirow[t]{2}{*}{11} & MF & 3223 & 5115 & 5791 & 2642 & 4912 & 5275 & 2952 & 3446 & 4665 \\
\hline & $\mathrm{F}$ & 54 & 34 & 79 & 51 & 131 & 177 & 58 & 14 & 35 \\
\hline \multirow[t]{2}{*}{10} & MF & 28 & 47 & 130 & 2679 & 627 & 808 & 70 & 240 & 367 \\
\hline & $\mathrm{F}$ & 0 & 1 & 2 & 7 & 8 & 36 & 18 & 6 & 16 \\
\hline \multirow[t]{2}{*}{9} & MF & 771 & 1509 & 4189 & 22 & 28 & 621 & 84 & 352 & 1143 \\
\hline & $\mathrm{F}$ & 1 & 58 & 67 & 0 & 12 & 70 & 1 & 26 & 64 \\
\hline \multirow[t]{2}{*}{8} & MF & 3090 & 3806 & 3948 & 664 & 4 & 3 & 732 & 545 & 725 \\
\hline & $\mathrm{F}$ & 46 & 1 & 26 & 17 & 0 & 0 & 52 & 1 & 27 \\
\hline \multirow[t]{2}{*}{7} & MF & 16603 & 19846 & 18974 & 5962 & 4751 & 4775 & 3433 & 3518 & 5192 \\
\hline & $\mathrm{F}$ & 513 & 936 & 1104 & 237 & 199 & 187 & 46 & 42 & 128 \\
\hline 6 & MF & 319 & 1022 & 1375 & 22 & 21 & 34 & 61 & 253 & 767 \\
\hline & $\mathrm{F}$ & 1 & 23 & 9 & 3 & 0 & 0 & 21 & 0 & 10 \\
\hline 5 & MF & 2927 & 4055 & 4162 & 2917 & 2770 & 2796 & 2497 & 2426 & 3993 \\
\hline & $\mathrm{F}$ & 37 & 56 & 47 & 113 & 93 & 71 & 52 & 43 & 58 \\
\hline 4 & MF & 8438 & 9257 & 9376 & 180 & 208 & 365 & 32 & 196 & 289 \\
\hline & F & 2 & 5 & 40 & 0 & 1 & 4 & 0 & 1 & 2 \\
\hline 3 & MF & 2238 & 2682 & 2713 & 322 & 284 & 265 & 525 & 1146 & 1536 \\
\hline & $\mathrm{F}$ & 9 & 7 & 16 & 0 & 0 & 0 & 0 & 1 & 6 \\
\hline 2 & MF & 3892 & 5257 & 5359 & 2744 & 1773 & 2210 & 217 & 5223 & 7397 \\
\hline & $\mathrm{F}$ & 1 & 5 & 35 & 7 & 14 & 14 & 1 & 13 & 28 \\
\hline 1 & MF & 6357 & 5642 & 5556 & 5240 & 6468 & 6405 & 2732 & 3684 & 6036 \\
\hline & $\mathrm{F}$ & 77 & 88 & 87 & 33 & 33 & 74 & 37 & 27 & 119 \\
\hline
\end{tabular}


Table 8

Compound Growth Rates of Female Employment in the Most Labour-intensive Departments (1983 through 1989)

\begin{tabular}{cccc}
\hline BPS & Communications & Finance & Railways \\
\hline All Grades & 13.21 & 8.28 & 13.44 \\
22 & $\mathrm{NC}$ & $\mathrm{NC}$ & $\mathrm{NC}$ \\
21 & $\mathrm{NC}$ & $\mathrm{NC}$ & $\mathrm{NC}$ \\
20 & $\mathrm{NC}$ & 12.25 & $\mathrm{NC}$ \\
19 & 0.00 & 16.50 & $\mathrm{NC}$ \\
18 & 0.00 & 8.15 & -13.17 \\
17 & 27.68 & 16.76 & 45.53 \\
16 & 25.99 & 16.50 & 20.09 \\
15 & $\mathrm{NC}$ & $\mathrm{NC}$ & $\mathrm{NC}$ \\
14 & $\mathrm{NC}$ & 11.57 & 19.72 \\
13 & $\mathrm{NC}$ & 8.89 & $\mathrm{NC}$ \\
12 & 63.35 & $\mathrm{NC}$ & 57.04 \\
11 & 6.55 & 23.05 & -8.07 \\
10 & $\mathrm{NC}$ & 31.38 & -1.94 \\
9 & 101.53 & $\mathrm{NC}$ & 100.00 \\
8 & -9.07 & $\mathrm{NC}$ & -10.35 \\
7 & 13.63 & -3.87 & 18.60 \\
6 & 44.22 & $\mathrm{NC}$ & -11.63 \\
5 & 4.07 & -7.45 & 1.84 \\
4 & 64.75 & $\mathrm{NC}$ & $\mathrm{NC}$ \\
3 & 10.06 & $\mathrm{NC}$ & $\mathrm{NC}$ \\
2 & 80.86 & 12.25 & 74.26 \\
1 & 2.06 & 14.41 & 21.49 \\
\hline
\end{tabular}

Note: NC implies not computable.

\section{A CRITICAL REVIEW OF THE AVAILABLE CENSUS REPORTS}

In a society like Pakistan where the dominant force, patriarchy, keeps women subservient, only a few women work through their own choice. Usually they enter the workforce either to share the financial burden of their family with the male members of the household or, in the absence of any male member (due to widowhood, divorce or separation), to financially support their family. Due to the existing socio-cultural constraints, women's development has been badly neglected at the policy level. This is 
evident from the census reports of the Federal Government Civil Servants, prepared by the Cabinet Secretariat. The questionnaire is designed to collect the information by pay scale, division, occupational group, province/region of posting, age group, length of continuous service, designation, status of appointment, highest educational level, training received within and outside the country, field of specialisation, emoluments drawn, languages known, religion, marital status, number of dependents/children, ownership of vehicle and residential accommodation, domicile, citizenship of spouse, and insurance coverage by each federal employee regardless of sex. It is surprising that, despite collecting information on both male and female employees, gender-wise data is not published in these reports. In this section, we point out the importance of this unpublished information from the working women's point of view. In this context, we refer to the tables of the 1989 Census report, because this is the common pattern followed by the previous Census reports also.

(a) Section II of the Census Report presents the data on federal government civil servants by their designation and occupational group. Disaggregation by gender, despite the information being present, is not found in any of the tables even in such categories as physician, medical officer, principal, lecturers, teachers, librarians, nurses, and telephone operators. However, Table 18 presents information by gender for a very limited number of occupational groups, i.e., only for the BPS 17-22 category. It should be noted that only 9 percent of the total employees who are women fall in this category. It is surprising that the information on the women working in BPS-16 and below is not reported. While it has been observed (see Table 1) that the majority of women is concentrated in BPS-7 and BPS-9, which are mostly teachers, telephone operators, lady health visitors, librarians and clerks. The information on the occupational group for lower grades is very important from the policy point of view.

(b) Statistics on the region of posting are reported in Section III. This is not disaggregated by gender. Though the number of female civil servants in the federal government posted in other provinces/regions is not significant; it has profound policy implications not only in terms of accommodation, transport, children's schooling, etc., but also in terms of personal security.

(c) Section IV displays the information on the nature of employment of total federal employees. It is, therefore, difficult to assess the promotion and transfer criterion for women based on this limited available information.

(d) The data on age and continuous service, which is presented in Section IX, are also not disaggregated by gender. Information on the length of continuous service is important in evaluating the current position of women. Unfortunately this collected information is not published. 
(e) Section $\mathrm{X}$ reports the aggregated data on academic qualification, field of specialisation, and foreign training. Non-reporting of female employees in this important section is surprising. Is it because the majority of females are denied the opportunity of foreign training, which, of course, then hampers their appointment or promotion to higher positions? The reason for not publishing the information on the highest educational attainment and domestic training is not clear.

(f) Data on marital status and dependent children for the total federal employees are reported in Section XII. The importance of the concealed information on females is evident from many studies which conclude that divorcees, separated and widowed women with dependent parents and children are more likely to work than the married or well-placed women. Similarly, there is strong evidence that the number of female-headed households is quite substantial. Ignoring such an important factor limits the formulation and implementation of policy for the betterment of females.

(g) Statistics on the ownership of house and transport is also not available genderwise. Just to say that it is a small number is not enough. Why is this a small number? Why is it that the ownership of house and transport is not in the name of females, even in the officer grades? Does this indicate that the so-called independent women working at relatively better positions are also subservient?

\section{CONCLUSIONS AND POLICY RECOMMENDATIONS}

The objective of this paper was to examine the trends in female employment at the federal level and to show how important the information that is collected but not published is for working women from the policy point of view. And the important objective was to raise the pertinent, policy-relevant questions that arise from a preliminary examination of these data. This paper finds that the promotion of women remains very low as compared to men. Their majority is concentrated in the lower grades, and for the period of the study they are kept out of the two highest grades even in jobs that directly affect women's welfare. The lack of information on various components is badly felt; for example, about designation, region of posting, highest educational level, foreign and domestic training received, marital status, number of dependents, house and transport ownership, etc. This information has serious policy implications with regard to the planning for women's development, for which the government has set up a separate ministry.

It is strongly recommended that all the collected statistics on both sexes should be published. It would be helpful in determining the reasons why the majority of female workers is concentrated in the lower grades. Do they have equal opportunity and access to the educational and training institutions? Does the federal government have enough vacancies to absorb a sufficient proportion of the female labour force in various grades? 
This would greatly enhance the job of the Ministry of Women's Development and other relevant planning agencies to improve the working conditions for women, especially for single women with dependent parents and children.

\section{REFERENCES}

Pakistan, Government of (1983) Federal Government Civil Servants Census Report. Islamabad: Pakistan Public Administration Research Centre, Cabinet Secretariat.

Pakistan, Government of (1986) Federal Government Civil Servants Census Report. Islamabad: Pakistan Public Administration Research Centre, Cabinet Secretariat.

Pakistan, Government of (1989) Federal Government Civil Servants Census Report. Islamabad: Pakistan Public Administration Research Centre, Cabinet Secretariat. 


\section{Comments}

This paper seems to be an attempt at negating all the successive government policies on promoting female employment at all levels. It also negates the contribution of women who are working in the government sector in such large numbers. All the tables based on compound growth rates belie the surge in female employment. Therefore, I shall limit my comments only to Table 2.

The authors do not provide the logic for using the compound growth rates rather than the percentage changes, which appear to be more meaningful and appropriate for a short span of six years. Furthermore, it is not clear why the compound growth rate is calculated over the period 1983-89 when absolute figures show very conveniently that the major break through in female employment occurred in 1986. See Table 1. In percentage terms, female employment in the civil service increased by 118 percent between 1983-86 and by 21 percent during 198689. Therefore, the compound growth rate of 17 percent between 1983-89 does not make sense.

With reference to the decline in female employment in Table 2, I have some serious reservations. First, in Grade 13, while female employment declined by 11 percent between 1986-89 male employment declined by 46 percent in the same period. Another interesting feature with reference to these declining statistics is that both male and female employment have gone through more significant increases and decreases in 1986 than in 1989. This shows that the authors have not studied their statistics carefully but have rather focused mainly on statistical techniques (which, as already mentioned, is not justified anywhere in the text) to sensationalise the results. It would be more appropriate to calculate just percentage changes between the three points of time for both males and females to give a more balanced and true picture. This appears to be a distortion of facts. Furthermore, there is no analysis of this phenomenon of changes in male and female employment. There could be a number of possible reasons, e.g., females tend to quit jobs on marriage, temporary absence from the labour market, etc.; but the most important fact remains that males in general are the main and primary breadwinners for the family. Secondly, the authors have implied in Table 2 that women are concentrated in the lower grades, and have conveniently overlooked the statistics in Table 1 , which shows that there is an equally high concentration of men in the lower grades. Thirdly, women working in the lower grades largely belong to the category of labour force which would take up a job in times of dire necessity. Their low educational levels are their main handicap. This fact is corroborated by he statistics on male and female employment in Grade 20 during 1983-86 and 1986-89. While female employment in Grade 20 increased by 70 percent during 1983-86, the corresponding increase for males in Grade 20 
was only 26 percent. Similarly, during 1986-89, females in Grade 20 registered an increase of 20 percent, while the increase for males was only 6 percent.

The discussion with reference to Table 2, of compound growth rates, seems to be misleading as the results reported are not based on an appropriate technique used. The same impression is created by the rest of the tables, based on compound growth rates all through the paper. Therefore, it is strongly advised that the authors should examine their statistics carefully and analyse them with reference to the factors related to these statistics. A comparative analysis of statistics on both male and female employment should be undertaken to avoid misrepresentation of facts. Most important, a simple and more appropriate technique, taking into account all the three periods, should be used to have any meaningful analysis.

Shahnaz Rauf

Federal Government Girls College,

F-7/2, Islamabad. 